OPEN ACCESS

Edited by:

Elsa Lamy,

University of Évora, Portugal

Reviewed by:

Anderson Fernando de Souza, University of São Paulo, Brazil

F. Capela e Silva,

University of Evora, Portugal

*Correspondence:

Gabriel Rueda-Carrillo grueda@unam.mx

Specialty section:

This article was submitted to Animal Nutrition and Metabolism,

a section of the journal

Frontiers in Veterinary Science

Received: 08 September 2021 Accepted: 31 December 2021

Published: 07 March 2022

Citation:

Rueda-Carrillo G, Rosiles-Martínez $R$, Hernández-García Al,

Vargas-Bello-Pérez E and

Trigo-Tavera FJ (2022) Preliminary

Study on the Connection Between the Mineral Profile of Horse Hooves and

Tensile Strength Based on Body Weight, Sex, Age, Sampling Location, and Riding Disciplines.

Front. Vet. Sci. 8:763935. doi: 10.3389/fvets.2021.763935

\section{Preliminary Study on the Connection Between the Mineral Profile of Horse Hooves and Tensile Strength Based on Body Weight, Sex, Age, Sampling Location, and Riding Disciplines}

\author{
Gabriel Rueda-Carrillo ${ }^{*}$, René Rosiles-Martínez ${ }^{1}$, Anaid Ireri Hernández-García ${ }^{1}$, \\ Einar Vargas-Bello-Pérez ${ }^{2}$ and Francisco J. Trigo-Tavera ${ }^{1}$ \\ 'Universidad Nacional Autónoma de México, Facultad de Medicina Veterinaria y Zootecnia, Departamento de Nutrición \\ Animal y Bioquímica, Ciudad Universitaria, Mexico City, Mexico, ${ }^{2}$ Department of Veterinary and Animal Sciences, Faculty of \\ Health and Medical Sciences, University of Copenhagen, Copenhagen, Denmark
}

Hoof mineral profile is important as it could affect locomotion. Factors such as body weight, sex, age, and riding disciplines affect hoof mineral profile. In Mexico and globally, studies are needed on the characterization of mineral profile of hooves and tensile strength, as this could help to prevent overgrowth or microfractures. Therefore, in the present survey, 165 samples of equine hoof cuttings from different sex, ages, breeds, and riding disciplines from different regions of Mexico were analyzed for their mineral composition, and a universal testing machine was used to measure tensile strength. More than half of the samples were from males (63\%) and aged 3 to 5 years (52\%). Most samples were obtained from horses used for reproduction (36\%) and working (29\%) purposes. The most preponderant minerals were $\mathrm{K}(3,416 \mu \mathrm{g} / \mathrm{g})$, Na $(2,242 \mu \mathrm{g} / \mathrm{g})$, and $\mathrm{Ca}(631 \mu \mathrm{g} / \mathrm{g})$. Tensile strength ranged from 1.2 to $45 \mathrm{~N}$. Females had higher $(P<0.05)$ amounts of $\mathrm{Zn}$ than males. Animals younger than 3 years old have lower $(P<0.05)$ levels of $\mathrm{Na}$ than those between 3 and 5 years old. Horses used for reproduction had lower $(P<0.05) \mathrm{Mg}$ concentrations than animals used for running and working. Tensile strength was similar between demographic characteristics. Horses from Santa Gertrudis military ranch had higher $(P<0.05)$ levels of $\mathrm{Ca}$, Se, and $\mathrm{Na}$ compared with horses from other sampling location. Copper was higher $(P<0.05)$ in horses from racecourse. Potassium was higher $(P<0.05)$ in horses from the Presidential General Staff. Overall, there was no evident connection between sex, ages, breeds, and riding disciplines from different regions of Mexico and the mineral composition of the hoof or its tensile strength. Further research should focus on the relation on specific feeding regimes, horse individual characteristic, hoof mineral contents, and tensile strength.

Keywords: equine hoof, minerals, tensile strength, hoof quality, riding discipline 


\section{INTRODUCTION}

Members of the Equidae family represent the result of a digitigrade evolution, as they rest on a finger, protected by a horn tissue covering called a hoof (1), which is divided into three parts: the wall, the sole, and the frog. The hoof wall is a highly keratinized structure that does not have blood vessels or nerves, as it is generated from the continuous cell division of a germ layer of basal cells, and provides protection for internal structures covering from the coronary border to the ground (2). The structure of the sole is similar to that of the horny layer of the wall, since it is composed of vertical keratin tubules; however, the sole is softer than the wall since it has a higher degree of humidity, and approximately one-third part of this structure is made up of water (3). Its main function is to protect the internal sensitive structures; however, the outer perimeter of the sole provides support, distributing part of the horse's weight with the hoof wall (4). The frog, also formed by keratinized tissue and a higher percentage of water, has greater flexibility than that of the rest of the hoof, and its main function is to carry out the hemodynamic flow.

The chemical characteristics of the horse's hoof depend on the body's nutrition, and its reflection will be part of the quality of the feed supplied (5). In this regard, an adequate supply of nutrients to the keratin-forming cells is essential for the quality and function of the hoof tissue. If nutrition is compromised, due to deficiency or excess of nutrients, it can cause delay or overgrowth of the hoof (6); other hoof problems associated with this can be thin walls and soles, microfractures (quarters), wall peeling, and interrupted growth patterns on the hoof wall (7). The growth rate and hoof chemical composition are of vital importance, as this affects ability to perform locomotion (8). Depending on the horse's genetics, diet, exercise, and the surrounding environment, the average growth rate is 0.6 to $1.3 \mathrm{~cm} /$ month (9).

Minerals comprise approximately $4 \%$ of body weight and are an essential part of the horse's diet as they help to metabolize proteins, fats, and carbohydrates; aid muscles and nerves to function properly; maintain the acid-base balance of body fluids; and are essential components of each enzyme required for metabolic functions (5). Horses require at least 15 different mineral elements, and some of these are required in relatively greater amounts such as calcium $(\mathrm{Ca})$, phosphorus $(\mathrm{P})$, sodium $(\mathrm{Na})$, potassium $(\mathrm{K})$, chlorine $(\mathrm{Cl})$, magnesium $(\mathrm{Mg})$, and sulfur $(\mathrm{S})$, while microminerals such as iron $(\mathrm{Fe})$, copper $(\mathrm{Cu})$, zinc $(\mathrm{Zn})$, manganese $(\mathrm{Mn})$, and selenium $(\mathrm{Se})$ are needed for keratinization in the living part of the hoof (10); however, with regard to microminerals, $\mathrm{Zn}$ and $\mathrm{Cu}$ are also important for improving hoof quality (11). That is why equine hoof characteristics such as its tensile strength, wear, and integrity, are associated with the chemical composition of the hoof and clearly depends on dietary nutrients (10-12).

Biomechanically, the purpose of the hoof is to transfer a large proportion of the ground reaction force between the hoof wall and the skeleton, which means that the hoof modulates irregularities in externally applied loads and attenuates the impact of its own contact with the hoof sole (13). Tensile testing measures the resistance of a material to a slowly applied

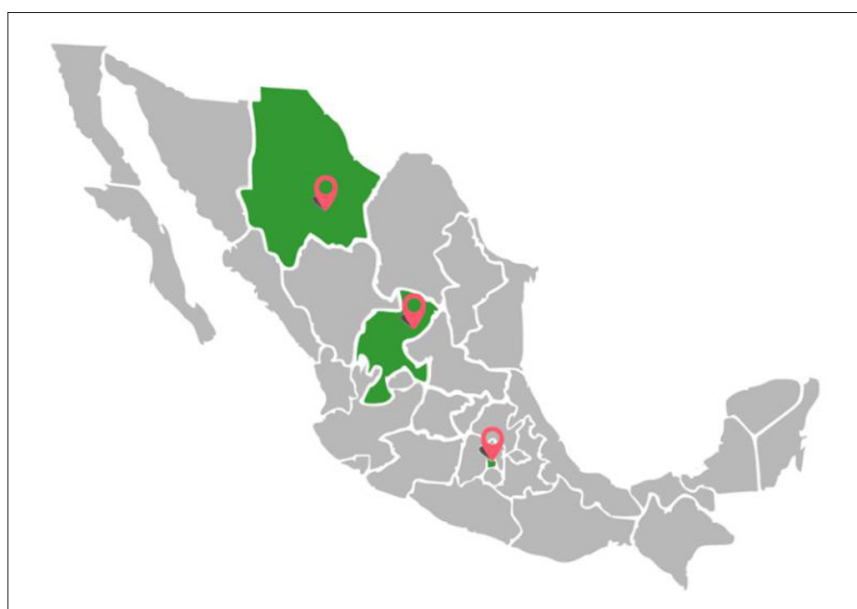

FIGURE 1 | A map of Mexico showing the three sampling locations.

quasi-static loading. A sample of any material is placed in the universal testing machine where tension and compression tests can be carried out. The effort obtained in the highest applied force is the tensile strength, which determines the force needed to break a sample. This value is also commonly known as the maximum tensile strength or breaking strength (14). In Mexico, data on the mineral profile of horse hooves and tensile strength is not available. However, this information is of vital importance for horse owners as it could be used to prevent health problems. Therefore, the objective of this survey was to determine the connection between sex, ages, breeds, and riding disciplines from different regions of Mexico and the mineral composition (Ca, $\mathrm{K}, \mathrm{Fe}, \mathrm{Mg}, \mathrm{Se}, \mathrm{Zn}, \mathrm{Na}$, and $\mathrm{Cu}$ ) of the hoof or its tensile strength.

\section{MATERIALS AND METHODS}

\section{Animals}

Hoof trim samples were obtained from 165 horses (37\% female and $63 \%$ male) without apparent locomotion problems and clinically healthy, aged $4.8 \pm 3.1$ years, with a mean body weight of $441 \pm 68 \mathrm{~kg}$. Samples were taken from three locations: (1) Mexico City (CDMX) [private ranch, mounted police, Presidential General Staff (PGS), racecourse, and military school, $n=82]$, (2) Chihuahua (Santa Gertrudis military ranch, $n=33$ ), and (3) Zacatecas (private ranch, $n=50$ ) (Figure 1).

Age was divided in categories using $33 \%$ and $66 \%$ percentiles (low values $<33 \%$, mean values $33-66 \%$, and high values $>66 \%$ ); thus, three categories were obtained: $<3$ years, $3-5$ years, and $>5$ years. Most of the animals chosen for the present study were young animals because it is the age range used for surveillance or working, and the surveyed horses belong to this riding discipline. Demographic data from surveyed horses is shown in Table 1.

\section{Hoof Samples}

Equine hoof samples $(65 \pm 21 \mathrm{~g})$ were obtained from hoof trimmings routinely performed on horses during shoeing and/or 
TABLE 1 | Demographic data from surveyed horses.

\begin{tabular}{|c|c|c|c|}
\hline \multicolumn{2}{|c|}{ Characteristic } & \multirow{2}{*}{$\begin{array}{c}\text { Frequency } \\
\qquad \begin{array}{c}(\boldsymbol{n}) \\
104\end{array}\end{array}$} & \multirow{2}{*}{$\begin{array}{c}\begin{array}{c}\text { Percentage } \\
(\%)\end{array} \\
63\end{array}$} \\
\hline Sex & Male & & \\
\hline & Female & 61 & 37 \\
\hline \multirow[t]{3}{*}{ Age } & $<3$ years & 47 & 28.5 \\
\hline & 3 to 5 years & 52 & 31.5 \\
\hline & $>5$ years & 34 & 20.6 \\
\hline \multirow[t]{6}{*}{ Breed } & Crossbreed (unknown breeds) & 50 & 30.3 \\
\hline & Pure blood & 34 & 20.6 \\
\hline & Spanish & 14 & 8.5 \\
\hline & Warmblood & 28 & 17.0 \\
\hline & Quarter horse & 27 & 16.4 \\
\hline & Azteca & 11 & 6.7 \\
\hline Sampling & Private ranch (Zacatecas) & 50 & 30.3 \\
\hline \multirow[t]{6}{*}{ location } & Santa Gertrudis military ranch & 33 & 20.0 \\
\hline & Mounted police & 22 & 13.3 \\
\hline & Presidential general staff & 18 & 10.9 \\
\hline & Private ranch (Mexico City) & 14 & 8.50 \\
\hline & Military school & 18 & 10.9 \\
\hline & Racecourse & 10 & 6.10 \\
\hline Riding & Reproduction & 59 & 35.8 \\
\hline \multirow[t]{6}{*}{ discipline } & Working & 47 & 28.5 \\
\hline & Surveillance & 26 & 15.8 \\
\hline & Racing & 10 & 6.10 \\
\hline & Dancing show & 14 & 8.50 \\
\hline & Maintenance & 6 & 3.60 \\
\hline & Dressage & 3 & 1.80 \\
\hline
\end{tabular}

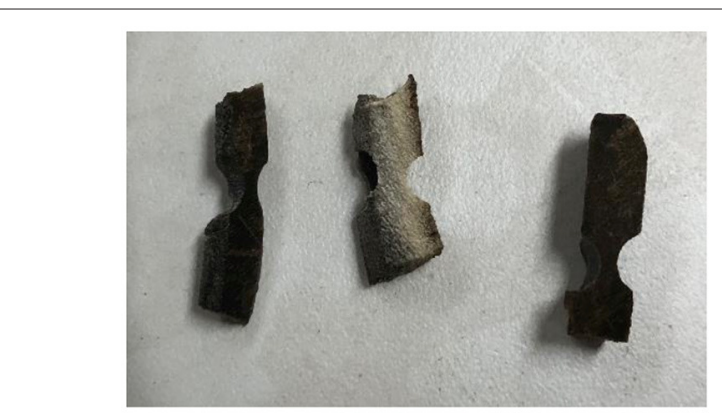

FIGURE 2 | Notched hoof samples.

trimming. Each sample was obtained from the right forelimb, from the area of the wall, from the bearing surface. Before trimming, each hoof was cleaned with a wire brush, then scrubbed with deionized water. Upon collection, clippings from each hoof were placed into labeled plastic bags and stored for subsequent analyses (15).

For tensile strength determination, samples were sliced to a uniform thickness of $0.5 \pm 0.1 \mathrm{~mm}$ and later cut to $5 \times$ $0.05 \mathrm{~cm}$. Then, samples were notched at their central area using a Dremel tool $\left(\right.$ Dremel $^{\circledR}$; Illinois, USA) to reach $2 \mathrm{~mm}$ of thickness. Samples that were not broken during notching were

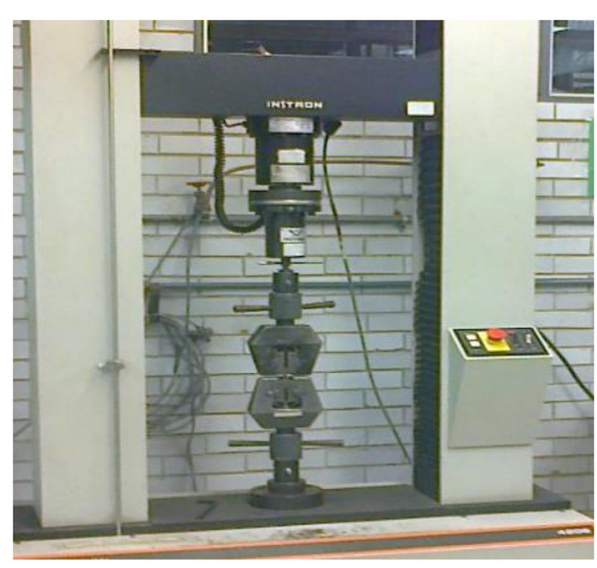

FIGURE 3 | Instron universal testing machine.

not considered for analysis because they did not have enough thickness for analysis. The rest of each hoof wall clipping was repackaged into labeled plastic bags and stored at room temperature until processed for mineral analysis (15) (Figure 2).

\section{Mechanical Testing}

The hoof tensile strength was measured with an Instron universal testing machine (Model 4206, Massachusetts, USA) with a load capacity of 5 kilonewtons (KN) (Figure 3) and an acceleration of $2 \mathrm{~mm} / \mathrm{min}$. This instrument allowed to measure hoof tensile strength, and results are expressed as $\mathrm{N}$, which is the number of kilograms over square millimeter required to break the sample. This measurement was achieved when a millimeter portion of the hoof trim (between 10 and $40 \mathrm{~mm}^{2}$ ) is held at the ends and subjected to tension until it breaks (15). All analyses were carried out during the first $48 \mathrm{~h}$ after collection, to ensure that the samples did not dehydrate. Samples had a dry matter content of $99 \%$, and all samples had the same handling and the same collection-testing time.

\section{Mineral Profile}

In order to determine the association, the hoof mineral elements ( $\mathrm{Ca}, \mathrm{K}, \mathrm{Fe}, \mathrm{Mg}, \mathrm{Se}, \mathrm{Zn}, \mathrm{Na}$, and $\mathrm{Cu}$ ) were measured from hoof trimming samples. Firstly, organic matter was removed, and then samples were pulverized and digested with nitric acid at $70^{\circ} \mathrm{C}$ for $12 \mathrm{~h} \mathrm{(15)} \mathrm{and} \mathrm{then} \mathrm{subjected} \mathrm{to} \mathrm{atomic} \mathrm{absorption} \mathrm{spectrometry}$ (Perkin Elmer 3100 Atomic Absorption Spectrometer, Waltham, Massachusetts, US). Samples from these studies were from animals that were monthly trimmed; therefore, samples from some animals were not enough to be used for mineral analysis.

\section{Statistical Analysis}

Depending on the type of variables, descriptive statistics (mean, standard deviation, frequencies, percentages, and 95\% confidence intervals for the means) were obtained for the mineral elements, tensile strength, and demographic characteristics of surveyed horses. To test for normality, the Shapiro-Wilk test was performed. A fixed-effects generalized linear model (GzLM) 
TABLE 2 | Main mineral contents $(\mu \mathrm{g} / \mathrm{g})$ from hoof samples.

\begin{tabular}{lccc}
\hline Mineral & $\boldsymbol{n}$ & $\begin{array}{c}\text { Mean } \pm \text { standard } \\
\text { deviation }\end{array}$ & $\begin{array}{c}\text { 95\% confidence } \\
\text { interval }\end{array}$ \\
\hline Potassium & 115 & $3,416 \pm 3,270$ & $2,812-4,020$ \\
Sodium & 115 & $2,242 \pm 1,102$ & $2,038-2,446$ \\
Calcium & 165 & $631 \pm 418$ & $566-695$ \\
Magnesium & 132 & $181 \pm 98.1$ & $164-198$ \\
Iron & 119 & $114 \pm 145$ & $88.5-141$ \\
Zinc & 165 & $79.1 \pm 55.0$ & $70.6-87.6$ \\
Selenium & 83 & $29.9 \pm 34.3$ & $22.4-37.4$ \\
Copper & 37 & $1.80 \pm 1.04$ & $1.46-2.15$ \\
\hline
\end{tabular}

(16) was used to compare the different characteristics of the horses. In the model, the dependent variables were minerals and tensile strength, and the remaining variables (sex, breed, age, sampling location, and riding discipline) were considered as factors. The differences $(P<0.05)$ among means were compared with Bonferroni test.

Principal component analysis (PCA) with the Varimax criterion and canonical discriminant analysis (CDA) were performed for mineral elements and tensile strength (17-19). Due to lack of information, some variables or categories of variables did not enter the analyses. Statistical analyses were performed with IBM SPSS Statistics ${ }^{\circledR}$ Version 27.

\section{RESULTS}

Potassium and $\mathrm{Na}$ were the most abundant minerals in hoof samples, while $\mathrm{Cu}$ was observed in lower quantities (Table 2). The tensile strength was $17.09 \pm 10.14 \mathrm{~N} / \mathrm{mm}^{2}$ (CI: $14.56-19.63$ $\mathrm{N} / \mathrm{mm}^{2}$ ) (Table 3). Due to the amount of available hoof sample, it was not possible to analyze the total amount of some minerals.

Table 3 shows mineral contents and tensile strength from hoof samples with regard to the different demographic characteristics of surveyed horses. Females had higher $(P<0.05)$ amounts of $\mathrm{Zn}$ than males. Animals younger than 3 years old have lower $(P$ $<0.05$ ) levels of $\mathrm{Na}$ than those between 3 and 5 years old. Horses used for reproduction had lower $(P<0.05) \mathrm{Mg}$ concentrations than animals used for running and working. Horses from Chihuahua had higher $(P<0.05)$ levels of $\mathrm{Ca}, \mathrm{Se}, \mathrm{K}$, and $\mathrm{Na}$ compared to horses from other sampling locations, but lower $\mathrm{Zn}$. Due to amounts of sample, $\mathrm{Cu}$ was only analyzed from CDMX, and the values were higher for racecourse $(2.22 \pm 0.99 \mu \mathrm{g} / \mathrm{g})$ and the lowest for the mounted police $(1.59 \pm 1.29 \mu \mathrm{g} / \mathrm{g})(P<0.05)$. Tensile strength $(P>0.05)$ was similar between all demographic characteristics. Horses from Santa Gertrudis military ranch had higher $(P<0.05)$ levels of $\mathrm{Ca}$, Se, and $\mathrm{Na}$ compared to horses from other sampling locations. Potassium was higher $(P<0.05)$ in horses from the Presidential General Staff.

The PCA resulted with two significant components where the Kaiser test explained $56.62 \%$ of total variation. Table 4 shows the results of Varimax rotation. The first factor explaining $32.29 \%$ of the variability was identified by six of seven variables $(\mathrm{Ca}, \mathrm{Mg}$, $\mathrm{Zn}, \mathrm{Na}$, and tensile strength), and the second factor $(24.33 \%$ of the variability) was identified by four of seven variables $(\mathrm{Mg}, \mathrm{Fe}$, $\mathrm{Zn}$, and tensile strength) (Figure 4).

The raw canonical coefficient of canonical discriminant functions by sex, age, breed, sampling location, and riding discipline was significant $(P<0.05)$ (Table 5). In canonical 1 (sampling location), $81.90 \%$ of the total variation was explained, and the most discriminating minerals were $\mathrm{Ca}, \mathrm{K}$, and $\mathrm{Na}$ with a positive correlation and $\mathrm{Zn}$ with a negative correlation. In canonical 2, $18.10 \%$ of the total variation was explained, and the most discriminating variables were Fe and tensile strength with a positive correlation and $\mathrm{Mg}$ with a negative correlation. Figure 5A shows that the private ranch (CDMX) was isolated from the rest of the sites by the lower influence of minerals in canonical 1, but more discriminated by $\mathrm{Zn}$.

For the breed trait, canonical 1 explained $74.7 \%$ of the total variation, and the most discriminating elements were as follows: $\mathrm{K}$ and tension strength having a positive correlation, and in canonical 2, the most discriminating elements were $\mathrm{Ca}$ and $\mathrm{Mg}$ having a negative correlation, and $23.80 \%$ of the total variation was explained. Figure 5B shows that the Spanish breed was found to be isolated from the rest of the breeds that entered the analysis, due to the lower influence of minerals found in canonical 1 .

For the riding disciplines, canonical 1 described $73.30 \%$ of the total variation, with $\mathrm{K}$ as the most discriminating mineral with a positive correlation. Canonical 2 explained $20.20 \%$ of the total variation, with $\mathrm{Mg}$ as the most discriminating mineral with a positive correlation. Canonical 3 explained $5.20 \%$ of the total variation, with $\mathrm{Fe}$ as the most discriminating mineral with a positive correlation. Canonical 4 described 1\%, being Fe has a positive correlation and is the most discriminating mineral, while canonical 5 explained $0.30 \%$ of the total variation, having the following as the most discriminating minerals: $\mathrm{Zn}$ with a positive correlation and $\mathrm{Na}$ and $\mathrm{Ca}$ with a negative correlation. Figure 5C shows that horses used for dancing show and reproduction were isolated from the rest of the riding disciplines, due to the lower influence of minerals found in canonical 1.

\section{DISCUSSION}

The hoof structure is very important for horse welfare and performance, and therefore, results obtained in this study seek to expand the knowledge and existing values on the mineral contents of horses' hooves, in addition to tensile strength values (20-22). Until today, studies on this topic from horses in Latin America are scarce. It is important to note that the animals from which the hoof sample was taken for this study had a macroscopic "healthy" external appearance, but no histological analysis was performed. Further studies should determine histology analysis to confirm hoof healthiness.

With regard to the concentration of minerals determined by age, horses under 3 years of age had higher levels of $\mathrm{Zn}$ compared to horses over 3 years of age, but $\mathrm{Na}$ levels were lower in younger horses. Zinc is a key mineral for keratinization process. The keratin cells of the upper part of the hoof lose their nucleus and organs; during this process, the cells die and form the corneal structure of the hoof (23). Zinc content in this 
TABLE 3 | Comparison of mineral elements with equine characteristics.

\begin{tabular}{|c|c|c|c|c|c|c|c|c|c|c|}
\hline \multirow[t]{2}{*}{ Variable } & \multirow[t]{2}{*}{$n$} & \multicolumn{8}{|c|}{ Mineral elements $(\mu \mathrm{g} / \mathrm{g})$} & \multirow{2}{*}{$\begin{array}{c}\text { Tensile } \\
\text { strength } \\
\left(\mathrm{N} / \mathrm{mm}^{2}\right)\end{array}$} \\
\hline & & $\mathrm{Ca}$ & Mg & Se & $\mathrm{Fe}$ & $\mathrm{Zn}$ & $\mathbf{K}$ & $\mathrm{Na}$ & $\mathrm{Cu}$ & \\
\hline \multicolumn{11}{|l|}{ Sex } \\
\hline Male & 104 & $679 \pm 437$ & $189 \pm 94$ & $34 \pm 35$ & $125 \pm 163$ & $73 \pm 51^{b}$ & $2,968 \pm 3,049$ & $2,135 \pm 1,067$ & $1.76 \pm 0.89$ & $16 \pm 10$ \\
\hline Female & 61 & $550 \pm 374$ & $166 \pm 105$ & $26 \pm 34$ & $102 \pm 119$ & $89 \pm 60^{a}$ & $4,530 \pm 3,576$ & $2,508 \pm 1,161$ & $1.91 \pm 1.39$ & $22 \pm 10$ \\
\hline \multicolumn{11}{|l|}{ Age } \\
\hline$<3$ years & 47 & $602 \pm 385$ & $172 \pm 109$ & $20 \pm 23$ & $124 \pm 168$ & $89 \pm 57$ & $3,927 \pm 3,077$ & $1,875 \pm 1,006^{a}$ & $1.91 \pm 0.94$ & $20 \pm 10$ \\
\hline $3-5$ years & 52 & $525 \pm 413$ & $151 \pm 107$ & $33 \pm 41$ & $113 \pm 134$ & $78 \pm 59$ & $5,228 \pm 4,154$ & $3,038 \pm 1,042^{b}$ & $2.93 \pm 1.51$ & $17 \pm 0.4$ \\
\hline$>5$ years & 34 & $831 \pm 563$ & $235 \pm 78$ & $44 \pm 27$ & $113 \pm 134$ & $73 \pm 52$ & $3,706 \pm 3,032$ & $2,267 \pm 1,086^{a b}$ & $1.49 \pm 1.19$ & $22 \pm 10$ \\
\hline \multicolumn{11}{|l|}{ Breed } \\
\hline Azteca & 11 & $999 \pm 238$ & $281 \pm 69$ & & $82 \pm 114$ & $111 \pm 25$ & $2,101 \pm 554$ & $1,301 \pm 304$ & $1.50 \pm 1.12$ & $20 \pm 14$ \\
\hline Pure blood & 34 & $828 \pm 389$ & $206 \pm 40$ & $55 \pm 29$ & $147 \pm 187$ & $64 \pm 56$ & $3,826 \pm 3,168$ & $2,364 \pm 1,016$ & $2.03 \pm 1.12$ & $21 \pm 6$ \\
\hline Warmblood & 28 & $805 \pm 569$ & $203 \pm 58$ & $68 \pm 35$ & $135 \pm 145$ & $21 \pm 27$ & $6,412 \pm 3,958$ & $3,253 \pm 962$ & & \\
\hline Spanish & 14 & $672 \pm 141$ & $163 \pm 89$ & & $50 \pm 21$ & $79 \pm 72$ & $867 \pm 301$ & $978 \pm 545$ & $1.90 \pm 0.46$ & $15 \pm 13$ \\
\hline Crossbred & 50 & $492 \pm 290$ & $169 \pm 97$ & $8 \pm 3$ & $109 \pm 145$ & $98 \pm 39$ & $1,674 \pm 680$ & $2,096 \pm 701$ & $2.02 \pm 1.03$ & $15 \pm 7$ \\
\hline Quarter horse & 27 & $250 \pm 108$ & $145 \pm 126$ & $8 \pm 3$ & $104 \pm 131$ & $108 \pm 52$ & & & & \\
\hline \multicolumn{11}{|c|}{ Riding discipline } \\
\hline Dressage & 3 & $916 \pm 152$ & $231 \pm 7^{\mathrm{ab}}$ & & $45 \pm 39$ & $115 \pm 18$ & $1,769 \pm 182$ & $1,296 \pm 155$ & $2.07 \pm 0.79$ & $14 \pm 9$ \\
\hline Growing & 6 & $915 \pm 169$ & $313 \pm 65^{a b}$ & & $45 \pm 28$ & $124 \pm 15$ & $2,122 \pm 544$ & $1,122 \pm 243$ & $1.61 \pm 1.10$ & $20 \pm 14$ \\
\hline Racing & 10 & $788 \pm 294$ & $204 \pm 43^{a}$ & & $147 \pm 225$ & $127 \pm 36$ & $1,532 \pm 502$ & $1,206 \pm 184$ & $2.22 \pm 0.99$ & $20 \pm 5$ \\
\hline Surveillance & 26 & $721 \pm 240$ & $227 \pm 64^{\mathrm{ab}}$ & & $132 \pm 132$ & $83 \pm 36$ & $1,646 \pm 695$ & $2,137 \pm 683$ & $2.16 \pm 1.08$ & $16 \pm 9$ \\
\hline Dance & 14 & $672 \pm 141$ & $163 \pm 89^{a}$ & & $50 \pm 21$ & $79 \pm 72$ & $869 \pm 301$ & $978 \pm 545$ & $1.90 \pm 0.46$ & $15 \pm 13$ \\
\hline Reproduction & 59 & $593 \pm 532$ & $131 \pm 89^{b}$ & $30 \pm 36$ & $114 \pm 134$ & $69 \pm 55$ & $5,271 \pm 3,758$ & $2,759 \pm 921$ & $0.38 \pm 0.41$ & $22 \pm 10$ \\
\hline Working & 47 & $529 \pm 412$ & $182 \pm 118^{a}$ & $29 \pm 33$ & $128 \pm 162$ & $71 \pm 59$ & $564 \pm 3,663$ & $3,216 \pm 945$ & & \\
\hline \multicolumn{11}{|c|}{ Sampling region } \\
\hline Mexico City & 82 & $740 \pm 255^{b}$ & $215 \pm 70$ & & $103 \pm 146$ & $90 \pm 44^{\mathrm{a}}$ & $1,558 \pm 713^{\mathrm{a}}$ & $1,771 \pm 771^{\mathrm{a}}$ & $2 \pm 1$ & $17 \pm 10$ \\
\hline Chihuahua & 33 & $947 \pm 592^{a}$ & & $63 \pm 34^{a}$ & $143 \pm 152$ & $6 \pm 6^{b}$ & $8,034 \pm 2,447^{b}$ & $3,414 \pm 917^{b}$ & & \\
\hline Zacatecas & 50 & $244 \pm 97^{b}$ & $126 \pm 112$ & $8 \pm 3^{b}$ & $105 \pm 141$ & $111 \pm 46^{a b}$ & & & & \\
\hline
\end{tabular}

${ }^{a-c}$ Different literals indicate significant differences $(P<0.05)$. 
TABLE 4 | Varimax rotation factor scores for the two-factor model for minerals in horse hooves.

\begin{tabular}{lcc}
\hline \multirow{2}{*}{ Mineral elements $(\boldsymbol{\mu} \mathbf{g} / \mathbf{g})$} & \multicolumn{2}{c}{ Components } \\
\cline { 2 - 3 } & $\mathbf{1}$ & $\mathbf{2}$ \\
\hline Sodium & 0.80 & -0.19 \\
Potassium & 0.77 & 0.05 \\
Calcium & 0.76 & 0.02 \\
Magnesium & 0.42 & 0.68 \\
Tensile strength $\left(\mathrm{N} / \mathrm{mm}^{2}\right)$ & 0.42 & -0.53 \\
Iron & -0.06 & -0.69 \\
Zinc & -0.30 & 0.67 \\
Variability (\%) & 32.29 & 24.33
\end{tabular}

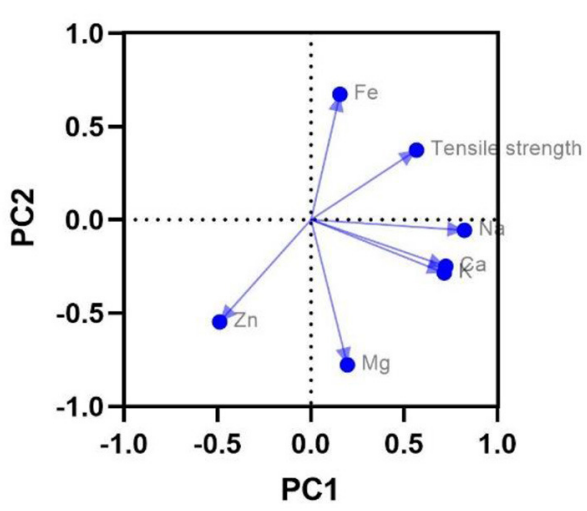

FIGURE 4 | Component plot of mineral elements and tensile strength of horse hooves.

study was higher in females than in males. In a study carried out in Iran (10), no relationship was not observed between $\mathrm{Zn}$ content and hoof quality. However, Tocci et al. (20) compared hoof quality of Anglo-Arab horses and Monterufoli ponies and reported that Anglo-Arab horses that had stronger hooves tended to accumulate more $\mathrm{Zn}$; however, in a study with donkeys' hooves (24), a negative relationship between hoof strength and $\mathrm{Zn}$ content was reported. Some researchers have chosen to study the effect of adding $\mathrm{Zn}$ to horse's diet. Most of these studies showed that $\mathrm{Zn}$ supplementation increases hoof quality for up to 1 year (10). Hepworth et al. assured that animals supplied with $\mathrm{Zn}$ and biotin could have improved hoof structure (25). In this regard, the hoof condition seems to be closely related to dietary nutrient (5).

Another factor that could affect hoof structure is the working hours that horses are subjected to, which implies physical and, therefore, physiological wear and tear. Not meeting nutritional requirements can lead to bone or tissue pathologies of hooves $(26,27)$. In the study, animals used for reproduction had lower $\mathrm{Mg}$ concentrations compared to those used for racing and work. Ozana da Silva and Manso Filho (28) measured the concentration of some blood minerals from mares in maintenance, pregnancy, lactation, and at parturition.
Lower values of $\mathrm{Mg}$ among pregnant and maintenance mares were reported, which could explain that in the hoof, rearing mares have lower values compared to race and working horses. Those differences could be due to the physiological wear and tear that pregnancy represents (28). Thus, further studies should consider blood hormone profiling together with diet analysis.

In the present study, sampling location was a factor that affected some mineral content in horse hooves. For example, $\mathrm{Zn}$ was higher in the Santa Gertrudis military ranch compared to the rest of the sampling locations, while $\mathrm{Na}$ was lower from samples obtained from a private ranch located in Mexico City. According to FAO, in arid and semi-arid areas such as the Santa Gertrudis military ranch located in Chihuahua State, there is usually an accumulation of exchangeable $\mathrm{Na}$ in the soil, which clearly increases $\mathrm{Na}$ content of the pastures in those regions (29). In this study, when using CDA, a separation of the samples from the private ranch from Mexico City was also observed with regard to the rest of the sampling locations. The effect of the sampling location has been reported in other species, for example, a study with donkey's hoof showed $\mathrm{Fe}$ levels of $437 \pm 65 \mathrm{ppm}$, and that was attributed to the grazing conditions that the animals had, in addition to high rainfall around the days of sampling. The authors mentioned that this could promote a highly acidic environment with consequent $\mathrm{Fe}$ solubilization, causing a greater absorption of this mineral into the hoof (24).

Although in the present study no significant differences were found using a generalized linear model between breeds, when using $\mathrm{CDA}$, it was observed that the canonical variables $\mathrm{Ca}$, $\mathrm{Mg}, \mathrm{Fe}, \mathrm{Zn}, \mathrm{K}, \mathrm{Na}$, and the tensile strength were separated between breeds, mainly associated with Spanish breed. Other studies have shown that hoof mineral contents vary between breeds and between species. For example, sole contents of $\mathrm{Ca}$ were higher in Anglo-Arab horses $(1,088 \pm 133 \mathrm{ppm})$ compared with Monterufoli Pony (373 $\pm 144 \mathrm{ppm})(20)$. In another study, higher hoof $\mathrm{Zn}$ values $(114 \pm 2 \mu \mathrm{g} / \mathrm{g})$ from ponies fed with a diet based on pellets and gelatin were reported (27), than those measured on donkey cuttings where $\mathrm{Na}$ values obtained were $267 \pm 15$ ppm (24).

It is important to consider that when carrying out this type of studies, the specific hoof area for sampling can yield to differences in mineral levels. For example, $\mathrm{Mg}$ levels obtained in this study were $181 \pm 98 \mu \mathrm{g} / \mathrm{g}$, while de Souza et al. (30) reported different $\mathrm{Mg}$ values from the wall (960 $\pm 631 \mathrm{ppm})$ and the frog $(1,389 \pm 768 \mathrm{ppm})$. Similarly, Tocci et al. (21) reported $\mathrm{Mg}$ values for the hoof wall of $373 \pm 33 \mathrm{ppm}$ and $255 \pm 38 \mathrm{ppm}$ for the sole. These discrepancies can be attributed to the fact that mineral contents will vary depending on the hoof sampling area, and therefore, during sampling, it is important to use the same sites in order to be comparable in the same study.

In this study, $\mathrm{K}$ and $\mathrm{Na}$ were the most preponderant minerals in hoof samples. In this study, Na was 2,242 $\pm 1,102 \mu \mathrm{g} / \mathrm{g}$, while other studies (31) have reported lower values ( $250 \pm 135 \mathrm{ppm})$. The K levels determined $(3,416 \pm 3,270 \mu \mathrm{g} / \mathrm{g})$ were higher than those mentioned by Sargentini et al. (1,690 $\pm 112 \mathrm{ppm})(24)$ and 
TABLE 5 | Raw canonical coefficient of canonical discriminant functions.

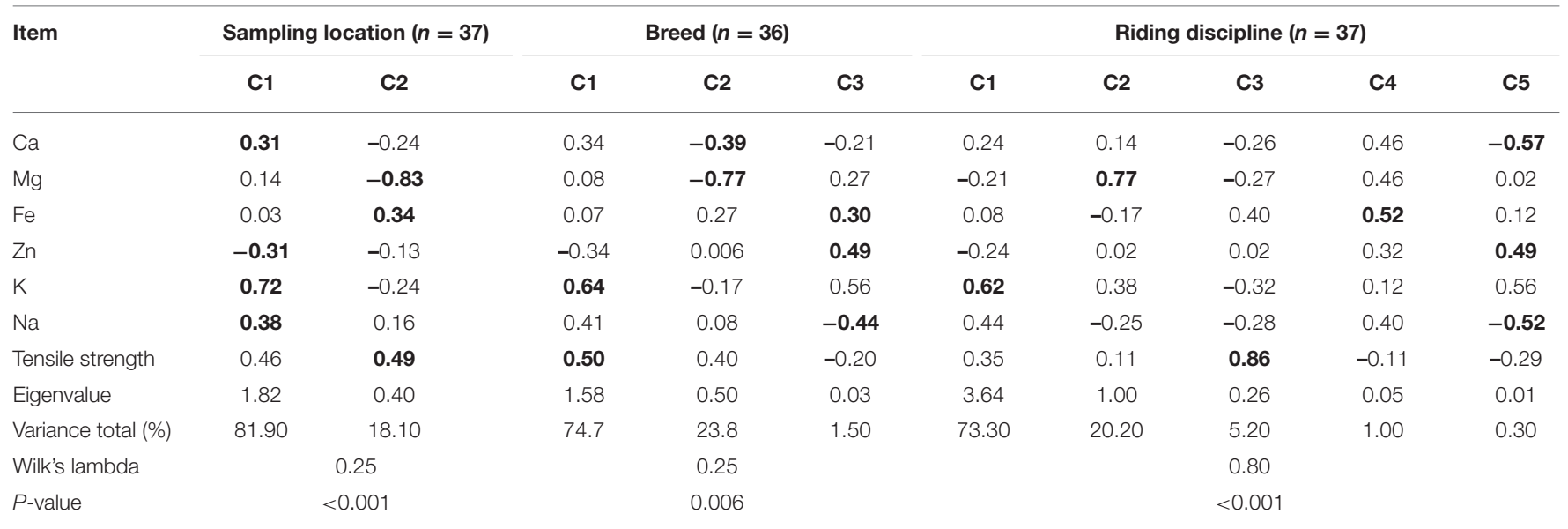

Bold values denote elements belonging to each canonical element.

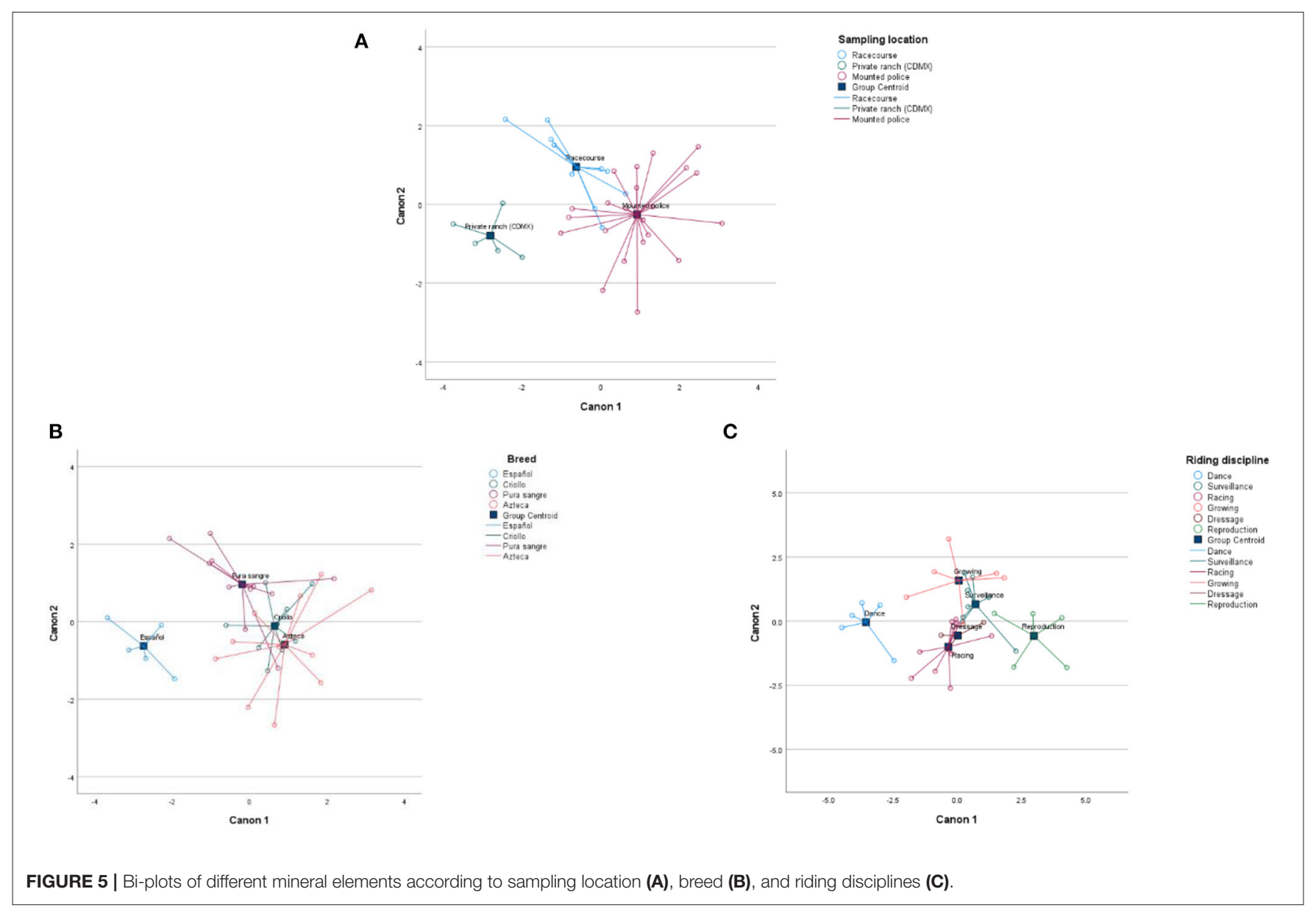

de Souza et al. (460 $\pm 425 \mathrm{ppm}$ ) (31). With regard to $\mathrm{Mg}$, values of $181 \pm 98 \mu \mathrm{g} / \mathrm{g}$ were obtained, while in mules and donkeys, de Souza et al. (11) indicated values of $840 \pm 922 \mathrm{ppm}$ and 1,178 \pm 855 ppm, respectively.

Calcium is a mineral to which more attention must be paid, as it helps to create cross-links of sulfur between the proteins of the hoof, allowing cohesion between cells (27). The stronger the cohesion, the healthier and more impenetrable the hoof will be. In the present study, there were values of 631.27 $\pm 418 \mu \mathrm{g} / \mathrm{g}$, and de Souza et al. obtained values in the wall area of $178 \pm 137 \mathrm{ppm}$, while in the frog, they were $366 \pm$ $180 \mathrm{ppm}$ (31). This is an indicative that even in the same structure, there are micro-zones with different concentrations of mineral elements. 
In the case of $\mathrm{Fe}$, a value of $114 \pm 145 \mu \mathrm{g} / \mathrm{g}$ was obtained, which is below the values $(290.58 \pm 256.26 \mathrm{ppm})$ reported by de Souza et al. (30). With regard to $\mathrm{Cu}$, an average of 1.80 $\pm 1.04 \mu \mathrm{g} / \mathrm{g}$ was obtained. This value was somewhat similar to that obtained by de Souza et al., $3.51 \pm 1.6 \mathrm{ppm}$ (30), but it was found below (4.3-4.53 ppm) that described by Faria et al. (32). In another study, by de Souza et al., Cu values of $5.61 \pm$ $1.38 \mathrm{ppm}$ were recorded (11). Copper has a very specific role in the growth of the hoof, as it is essential to build the keratin bridges present in the hoof. The sulfur in methionine and cysteine serves as a structural component that forms these bridges, and a copper-dependent enzyme in cells is responsible for building junctions between various proteins. If $\mathrm{Cu}$ is deficient, enzyme activity decreases, and the structural bridge is compromised. Ultimately, it is likely that the growth of these protein bridges will be affected, and in turn, this causes the hoof to show cracks from the growth (11).

On the other hand, the metabolic inter-relationship (antagonistic or synergistic relationship) that exists between mineral elements must be considered (33). For example, in this study, zinc had an antagonistic relationship with selenium. From the PCA results, it was observed that in PC1, Ca, Ma, Zn, Na, and the tensile strength had a negative correlation with zinc. On the other hand, in PC2, there was a positive correlation together with $\mathrm{Mg}, \mathrm{Fe}$, and tensile strength. These relations should be further studied and also relate them to animal's feed.

Bertram and Gosline (7) stand out for being pioneers in the study of hoof tensile strength and concluded that the properties of keratinous materials are strongly influenced by their state of hydration. This could explain the difference between Geyer values (40 to $60 \mathrm{~N} / \mathrm{mm}^{2}$ ) (26) and those obtained in the present study ranging from 1.2 to $45 \mathrm{~N} / \mathrm{mm}^{2}$, probably because of different environmental, seasonal, and geographical conditions from the sampling locations. In a study in which tensile strength of 20 mares between 4 and 20 years old was measured, values of 21.70 to $35.32 \mathrm{~N} / \mathrm{mm}^{2}$ were reported (15). Some of those mares were pregnant, and probably that could be a factor that affects tensile strength, and thus, this should be considered when interpreting results on tensile strength as well as animal's age.

When performing PCA and CDA, the tensile strength was introduced as a variable, obtaining positive correlations in both tests. This suggests that there is a relationship between these variables and mineral elements. In this regard, Zenker et al. (34) reported values of hoof tensile strength between 60.3 and $68.3 \mathrm{~N} / \mathrm{mm}^{2}$ and coronary edge tensile strength from 52.6 to $62.9 \mathrm{~N} / \mathrm{mm}^{2}$. This indicates that the hoof has areas that deform differently with the horse's gait; therefore, it is important to try to have these structures in the best possible state, since poor conformation can cause growth abnormalities and development, which predisposes to hoof microfractures. Several studies (35-37) have shown that microfractures are the second most recurrent hoof problem. On the other hand, it has to be considered that in those studies, the measurement of tensile strength was performed post mortem using tendons, ligaments, and cartilage (38-40), while in the present study, samples were obtained from hooves of live animals.

Lastly, carrying out these types of studies is difficult due to the sample amounts that can be obtained per animal. It must be considered that the animals have different conditions such as feeding regime, handling, and geographical location, and that is why it is necessary to have a well-defined inclusion criterion, which will lead to a greater number of samples and more robust results for mineral contents in horse hooves.

\section{CONCLUSIONS AND PERSPECTIVES}

Results from this survey offer a first profile and established a reference for mineral profile from Mexican horses with different characteristics. Overall, there was no evident connection between sex, ages, breeds, and riding disciplines from different regions of Mexico and the mineral composition of the hoof or its tensile strength. Further research should focus on the relation on specific feeding regimes, horse individual characteristic, hoof mineral contents, and tensile strength.

\section{DATA AVAILABILITY STATEMENT}

The raw data supporting the conclusions of this article will be made available by the authors, without undue reservation.

\section{ETHICS STATEMENT}

Ethical review and approval was not required for the animal study because samples were collected from private owners and no animal manipulation was involved. Written informed consent for participation was not obtained from the owners because samples obtained were when horse hooves were trimmed, owners just allowed us to remove the small pieces from trimmed hooves.

\section{AUTHOR CONTRIBUTIONS}

RR-M contributed to conception and design of the study. GR-C organized the database and made the sampling and processing of the studied materials. AH-G performed the statistical analysis. GR-C and EV-B-P wrote the first draft of the manuscript and sections of the manuscript. FT-T is the main tutor of the study and he reviewed the results obtained and the manuscripts. All authors contributed to the article and approved the submitted version.

\section{FUNDING}

This study was funded by the Universidad Nacional Autónoma de México, Facultad de Medicina Veterinaria y Zootecnia, Departamento de Nutrición Animal y Bioquímica.

\section{ACKNOWLEDGMENTS}

Special thanks to Dr. Ramiro Calderón Villa, Coronel Enrique Zedillo, Dr. David De Luna, and Roxana P. Izquierdo Chávez. 


\section{REFERENCES}

1. Pollit CC. Anatomy and physiology of the inner hoof wall. Clin Tech Equine Pract. (2004) 3:3-21. doi: 10.1053/j.ctep.2004.07.001

2. Hood DM. Physiology of the foot and normal growth Second international equine conference on laminitis and diseases of the foot. JEVS. (2004) 24:23440. doi: 10.1016/j.jevs.2004.05.009

3. Williams Gail, Deacon Martin. Sin pie no hay caballo. Spain: Hispano Europea editorial (2008).

4. Denoix J M. The Equine Distal Limb: Atlas of Clinical Anatomy and Comparative Imaging. CRC Press USA (2000).

5. Basurto R, Arrieta L, Castrejón H, Martínez JA, Herrera CA. Effect of zinc methionine on the equine hoof: an evaluation by environmental scanning electron microscopy. Vet Mex. (2008) 39:247-53.

6. Teskey TG. The unfettered foot: a paradigm changes for equine podiatry. $J$ Equine Vet Sci. (2005) 25:77-83. doi: 10.1016/j.jevs.2005.01.011

7. Bertram JE, Gosline JM. Functional design of horse hoof keratin: the modulation of mechanical properties through hydration effects Canada. J Exp Biol. (1978) 130:121-36. doi: 10.1242/jeb.130.1.121

8. Nauwelaerts S, Hobbs SJ, Back W. A horse's locomotor signature: COP path determined by the individual limb. PLoS ONE. (2017) 12:e0167477. doi: 10.1371/journal.pone.0167477

9. Faramarzi B, Thomason JJ, Sears WC. Changes in growth of the hoof wall and hoof morphology in response to regular periods of trotting exercise in Standardbreds. Am J Vet Res. (2009) 70:1354-64. doi: 10.2460/ajvr.70.11.1354

10. Noormohammady Z, Chamani M, Khodae HR. Effect of zinc on integrity of horse hoof. Research in: Agricultural and Veterinary Sciences. (2018) 2:17-23.

11. de Souza AF, Schade J, Laus R, Moreira MA, Muller TR, Fonteque JH. Differences in mineral concentrations on hooves of horses, mules and donkeys. Revista Brasileira de Ciência Veterinária. (2019) 26. doi: 10.4322/rbcv. 2019.017

12. Hidiroglou M, Williams CJ. Mineral and amino acid composition of beef cattle hooves. Am J Vet Res. (1986) 47:301-3.

13. Kauffmann S, Cline C. The Essential Hoof Book: The Complete Modern Guide to Horse Feet. Editorial Trafalgar Square (2017).

14. Askeland Donald R, Fulay Pradeep P, Wendelin J. Wright, Ciencia e ingenieria de los materiales. México: CENGAGE Learning (2012).

15. Ley W, Scott R, Dunnington E. Effects of season and diet on tensile strength and mineral content of the equine hoof wall. Equine Vet J. (1998) 26:4650. doi: 10.1111/j.2042-3306.1998.tb05121.x

16. McCulloch C, Neuhaus J. Generalized linear mixed models. In: Armitage P, Colton T, editors. Encyclopedia of Biostatistics. Chichester: John Wiley \& Sons (2005).

17. Jolliffe IT, Cadima J. Principal component analysis: a review and recent developments. Phil Trans $R$ Soc A. (2016) 374:20150202. doi: 10.1098/rsta.2015.0202

18. Tocci R, Sargentini C. Hoof characteristics of Anglo-Arabian, Haflinger, Monterufoli and Maremmano horse. Iran. J Appl Anim Sci. (2020) 10:341-7.

19. Barbera S, Biolatti B, Divari S, Cannizzo FT. Meat quality traits and canonical discrminant analysis to identify the use of illicit growth promoters in Charolais bulls. Food Chem. (2019) 300:125173 doi: 10.1016/j.foodchem.2019.125173

20. Tocci R, Sargentini C, Martini A, Giorgetti A. Quantitative hoof characteristics in Anglo -Arabian horses and Monterufoli ponies reared in the same farm. GJASR. (2015) 3:20-9.

21. Tocci R, Sargentini C, Martini A, Andrenelli L, Pezzati A, Benvenuti D, et al. Hoof quality of Anglo - Arabian and Haflinger horses. J Vet Res. (2017) 61:367-73. doi: 10.1515/jvetres-2017-0049

22. Georgievskii VL, Annekon BN, Samokhin VT. Mineral nutrition of animals Buttherworths, London (1981).

23. Mulling C. The use of nutritional factors in prevention of claw Diseases-Biotin as an example for nutritional influences on formation and quality of hoof horn. In: Mortellaro CM, De Vecchis L, Brizzi A, editors. $11^{\text {th }}$ international Symposium on Disorders of the Ruminant Digit. Parma, Italy (2000). p. 78-80.

24. Sargentini C, Tocci R, Andrenelli L, Giorgetti A. Preliminary studies on hoof characteristics in Amiata donkey. Ital J Anim Sci. (2012) 11:e22. doi: 10.4081/ijas.2012.e22

25. Hepworth KM, Neary M, Kenyon S. Hoof Anatomy, Care and Management in Livestock. Purdue University Cooperative Extension Service, West Lafayette (2004).
26. Geyer H. Nutritional management to keep the hoof healthy. In: Lindner A, editor. Applied equine nutrition. Wageningen Academic Publisher. The Netherlands. Equine Nutrition Conference (ENUCO) (2005). p. 43-59.

27. Butler KD, Hintz HF. Effect of level of food intake and gelatin supplementation on growth and quality of hooves of ponies. J anim Sci. (1977) 44:257-61. doi: 10.2527/jas1977.442257x

28. Ozana da Silva M, Manso Filho HC. Biochemical profile of Mangalarga Marchador mares during the last third of pregnancy, foaling and lactation. Ciencia Rural. (2019) 49:e20190200. doi: 10.1590/0103-8478cr20190200

29. FAO. Sodic soils and their management. Rome: de FAO (2021). Available online at: Fao.org/3/x5871e/x5871e05.html

30. Souza A, Mendes R, Schade J, Laus R, Moreira M, Müller T, et al. Podometry and mineral content in hooves of Campeiro horses. Pferdeheilkunde. (2021) 37:56-64. doi: 10.21836/PEM20210108

31. Tomlinson D, Mülling C, Fakler T. Invited Review: Formation of Keratins in the Bovine Claw: Roles of Hormones, Minerals, and Vitamins in Functional Claw Integrity. J Dairy Sci. (2004) 87:797-809. doi: 10.3168/jds.S0022-0302(04)73223-3

32. Faria GA, RezendeI ASC, Sampaio BM, Lana AMQ, Moura RS, Madureira JS, et al. Chemical composition of black versus non-pigmented hooves from Pantaneira and Mangalarga Marchador horses. Zootecnia e Tecnologia e Inspeção de Produtos de Origem Animal. Arq Bras Med Vet Zootec. (2005) 57. doi: 10.1590/S0102-09352005000500016

33. Belle C, Rammal W, Pierre J-L. Sulfur ligation in copper enzymes and models. J Inorg Biochem. (2005) 99:1929-36. doi: 10.1016/j.jinorgbio.2005.06.013

34. Zenker W, Josseck H, Geyer H. Histological and physical assessment of poor hoof horn quality in Lipizzaner horses and a therapeutic trial with biotin and a placebo. Equine Vet J.(1995) 27:183-91. doi: 10.1111/j.2042-3306.1995.tb03061.x

35. Holzhauer M, Bremer R, Santman-Berends I, Smink O, Janssens I, Back W. Cross-sectional study of the prevalence of and risk factors for hoof disorders in horses in The Netherlands. Prev Vet Med. (2017) 1:539. doi: 10.1016/j.prevetmed.2017.02.013

36. McGlinchey L, Robinson P, Porter B, Sidhu A, Rosanowski S. Quarter cracks in Thoroughbred racehorses trained in Hong Kong over a 9-year period (20072015): incidence, clinical presentation, and future racing performance. Equine Vet J. (2019) 32:18-24. doi: 10.1111/eve.13160

37. Sang-Kyung S, Su-Min K, Steve L, Gil-Jae C. Prevalence of Hoof Disorders in Horses in South Korea. Open Agric. (2020) 14:25-9. doi: 10.2174/1874331502014010025

38. Sharifi D, Kazemi D, Latifi H. Evaluation of tensile strength of the superficial digital flexor tendon in horses subjected to transcutaneous electrical neural stimulation therapeutic regimen. Am J Appl Sci. (2009) 6:816-9. doi: 10.3844/ajas.2009.816.819

39. Bowser JE, Elder SH, Rashmir-Raven AM, Swiderski CE. A cryogenic clamping technique that facilitates ultimate tensile strength determinations in tendons and ligaments. Vet Comp Orthop Traumatol. (2011) 5:3703. doi: 10.3415/VCOT-10-09-0128

40. Charlebois M, McKee MD, Buschmann MD. Nonlinear tensile properties of bovine articular cartilage and their variation with age and depth. J Biomech Eng. (2004) 126:129-37. doi: 10.1115/1.1688771

Conflict of Interest: The authors declare that the research was conducted in the absence of any commercial or financial relationships that could be construed as a potential conflict of interest.

Publisher's Note: All claims expressed in this article are solely those of the authors and do not necessarily represent those of their affiliated organizations, or those of the publisher, the editors and the reviewers. Any product that may be evaluated in this article, or claim that may be made by its manufacturer, is not guaranteed or endorsed by the publisher.

Copyright (c) 2022 Rueda-Carrillo, Rosiles-Martínez, Hernández-García, VargasBello-Pérez and Trigo-Tavera. This is an open-access article distributed under the terms of the Creative Commons Attribution License (CC BY). The use, distribution or reproduction in other forums is permitted, provided the original author(s) and the copyright owner(s) are credited and that the original publication in this journal is cited, in accordance with accepted academic practice. No use, distribution or reproduction is permitted which does not comply with these terms. 